\title{
Artelogie
}

Recherche sur les arts, le patrimoine et la littérature de l'Amérique latine

5 | 2013

Femmes créatrices en Amérique latine : le défi de synthétiser sans singulariser

\section{"¿Cosas de Mujeres?": Feminist Networks of Collaboration in 1970s Mexico}

\section{Gabriela Aceves}

\section{OpenEdition}

\section{Journals}

Electronic version

URL: https://journals.openedition.org/artelogie/5618

DOI: $10.4000 /$ artelogie.5618

ISSN: 2115-6395

Publisher

Association ESCAL

Electronic reference

Gabriela Aceves, "' ¿Cosas de Mujeres?": Feminist Networks of Collaboration in 1970s Mexico", Artelogie [Online], 5 | 2013, Online since 16 October 2013, connection on 20 December 2021. URL: http://journals.openedition.org/artelogie/5618 ; DOI: https://doi.org/10.4000/artelogie.5618

This text was automatically generated on 20 December 2021.

Association ESCAL 


\title{
"¿Cosas de Mujeres?": Feminist Networks of Collaboration in 1970s Mexico
}

\author{
Gabriela Aceves
}

I thank Rosa Martha Fernández, Ana Victoria Jiménez and Mónica Mayer who kindly allowed me to interview them and look at their personal archives.

The Canadian Social Science and Humanities Research Council and the Mexican Consejo

Nacional para la Ciencia y Tecnología provided funds for the research of this article.

\section{Introduction}

1 On May 9, 1971, a group of fifteen women gathered at the Mother's Monument located in Parque Sullivan, near Mexico City's downtown district. The objective of the meeting was to demand a change in the ways the mass media manipulated mother's day celebrations and objectified female bodies. These women were responding to the call of journalist Marta Acevedo who had recently published an article describing the experiences and tactics of the women's movement in San Francisco, California. Acevedo's article invited Mexicans to analyze and take consciousness of their social condition and creative potential beyond motherhood (ACEVEDO, 1970). This meeting and Acevedo's article were the catalysts for the emergence of second wave feminism in Mexico (LAU, 1987).

2 Throughout the 1970s a diverse group of students, professionals and militants from left-leaning associations in Mexico City established a number of small consciousnessraising groups and several feminist collectives. They organized lively demonstrations, experimenting with different visual and performative languages, to demand the eradication of discrimination against women at all levels of society. By walking the streets of Mexico City, staging theatrical farces and using humor to demand an end to violence against women, as well as sexual, reproductive and representation rights, these women -and those who joined them-produced diverse and competing ways of 
embodying femininity. Through these street performances they made the body the site of articulation for political, sexual and cultural violence and, in doing so, they transgressed normative gendered divisions of public and private space. Women came together at these street demonstrations and exchanged ideas, developing feminist collectives and transnational networks of political and artistic solidarity. They made the personal political.

3 This paper traces one of such network of artistic collaboration through a discussion of the practices of Rosa Martha Fernández (Mexico DF), filmmaker; Mónica Mayer (Mexico DF, 1954), visual artist; and Ana Victoria Jiménez (México DF, 1941), photographer and publisher, to propose an alternative lens with which the participation of women within the histories of art and the legacies of feminisms in the plural (as a theoretical framework and a diverse political stance rather than fixed dogma) can be understood. Through this lens, I take the concerns of a Mexican group of self-declared feminist artists and second wave activists as a legitimate point of departure to interrogate the relationship between social, political and artistic movements: a relationship that haunts most narratives of twentieth century Mexican art history, which have seldom recognized the legacies of 1970s feminisms (CORDERO \& SAENZ, 2007). Through their collaborations in different media, these women produced creative interconnections between various fields and, in doing so, they questioned disciplinary boundaries and genres and, most importantly, the historical metanarratives that had traditionally defined the production of knowledge in the fields of art, feminisms and social movements.

4 The works and collaborations produced by these three artists interrogated the ways in which visual images and performative practices created and reproduced dominant power relations. Specifically, their work explored how the three artists experienced these relations in the production, distribution and reception of their work, and moreover, how these relations were explicitly gendered. Gender as category of analysis, is understood through the postulates of Joan Wallach Scott and Judith Butler who have defined it as a group of socially constructed and historically contingent discourses that, through various reiterations, mutually shape feminine and masculine identities as opposites (SCOTT, 1986: pp. 1053-1075; BUTLER, 1993). Considering the performative, historically contingent and mutually constitutive qualities of gender, I explore how the collaborations of Fernández, Mayer and Jiménez destabilized normative constructions used to define parameters of politically committed art, art institutions and art practices as exclusively masculine endeavors prevalent in 1970s Mexico. While many other constructs of difference, including class and race, intersect gender as a category of analysis, few studies on the history of artist collectives in Latin America adopt it as a framework of analysis. Gender is privileged in this analysis as I read the practices of these three artists and attend to the diverse structures of difference that are present in their work, which further disrupt fixed definitions of women and feminism (in the singular).

5 Parallel to the focus on gender that drives this discussion, another issue that brings together the work of Fernández, Jiménez and Mayer is a concern for the archive, which occurs in two moments:first, at the moment of creation, guided by their ongoing interest for documenting their own artistic practices;and, secondly,atamore recentselfreflexive understanding of the archival potential of their work.I explore these two distinct juncturesof their engagement with the archive inrelation to Jiménez's 
collection of photographs and ephemera of feminist-led demonstrations, the use of Jiménez's still photography as archival sources in Fernández's films and, finally, by proposing a reading of Mayer's installation El Tendedero as an archive. Their engagement with the archiveis understood as an embodied practice (SCHNEIDER, 2002), a collection of varied objects (BURTON, 2003) and as an 'epistemological technology' (STOLER, 2002) that disrupts and regulates the terms of historical discourses. If in Mexico, as Carlos Monsivaís has argued, historical discourses and the production of History is conceived of as a masculine territory (MONSIVÁIS, 2006), how does the engagement of Jiménez, Fernández and Mayer with the archive disturb the normative gendered divisions that structure knowledge production?

\section{Context and definitions of politically committed art}

6 The practices of Jiménez, Fernández and Mayerdeveloped at a crucial time for international women's rights battles and in the midst of a violent decade in which the Latin American region wrestled with the devastating consequences of the Cold War. In Mexico, the emergence of second wave feminisms took place under the populist administrations of presidents Luis Echeverría Álvarez (1970-1976) and president Jose López Portillo (1976-1982). Both presidents embarked on a series of reforms that opened up opportunities for the participation of women in public office and created political conditions that strengthened competing feminist agendas. However, their administrations had little tolerance for dissent. They continually used violence to dispel street demonstrations and brutally suppressed rural unrest and urban radical activity.

President Echeverría's administration began with a reformist campaign known as democratic opening, a populist strategy aimed at siding with disenfranchised and defiant sectors of the population in order to redeem his popularity and that of the ruling party, both severely damaged after the massacre of students in Mexico City in 1968. He implemented a series of wide-ranging reforms that targeted economic, political and cultural sectors including reforms to Article 4 of the Mexican Constitution, granting equal rights legislation for women (1974), and a nation wide family planning campaign that promoted the use of contraceptives (1974-1982). In 1975, Echeverría's administration hosted the First United Nations International Women's Year Celebration (IWY, 1975) in Mexico City, an event that placed the capital city at the center of international debates on women's rights. A significant number of Mexican feminist activists were in disagreement with the objectives and organizational structure of the IWY celebration as well as Echeverría's reforms targeting women's equity and family planning. Paradoxically, these initiatives prompted the establishment of wider feminist coalitions (LAU, 1987; GUEVARA, 2002). By 1979, in the context of president López Portillo's political reforms that allowed the legalization of various left-leaning organizations Frente Nacional por la Liberación y Los Derechos de las Mujeres (FNALIDM, 1979), an alliance that united several feminist collectives with leftist political parties, elaborated a project on voluntary motherhood legislation that was presented to Congress by end of year(ZAPATA, 2007). While Congress did not pass the legislative proposal and while their demands were generally rejected by a predominantly Catholic and conservative society, the activities of feminist activists concurrently with the populist endeavors of president Echeverría and López Portillo made women's issues 
part of the agenda for public debate. Within this agenda, the role of women in the visual arts also became a matter of discussion and contention.

Anticipating the international attention that the celebration of UN's IWY conference would bring to his government, Echeverría organized a series of art exhibitions aimed at showcasing women's creativity. These efforts were not well received by some feminist activists and artists (BARBOSA, 2008).For Mónica Mayer (personal communication, September 5, 2009), these exhibitions appeared to endow women with an equal participation in the arts, however, the majority of participants were men, and women were generally the predominant subject matter rather than active participants. Mayer suggests the works presented and the curatorial objective of these exhibitions failed to question how images represented the female body or conceptions of femininity (2009).

Following these events, in 1976, ArtesVisuales, a bilingual art magazine published by the Museum of Modern Art in Mexico City (MAM), dedicated an issue to discussing the participation of women in the arts (STELLWEG, 1976).The issue included a debate and interviews with Mexican academics, artists and art critics along with essays and interviews with US-based self-declared feminists artists and critics. These essays introduced the relevance of the emergent US feminist art movement for Mexican audiences, in particular the activities of the recently established Women's Art Building in Los Angeles, California (ZORA, 1976; LIPPARD, 1976; MOSSER, 1976).

Mexican-based art historians, artists and critics responded to a series of questions posed by Carla Stellweg, editor of the magazine, that revolved around the relative nonexistence of women artists compared to the dominance of women as art historians and critics; on whether formal feminine qualities existed in the works of women artists, and on whether a critique of women's conditions was present in the works of art made by Mexican female artists. While the objective of these questions was not to arrive at definite conclusions, but rather, to begin a discussion about the conditions of women artists in Mexico, they revealed the positions of the leading intellectuals in the field who continued to influence the art establishment. For instance, Teresa Del Conde considered that it was ludicrous to think that artistic expression had a sex (DEL CONDE, 1976: p. 18), while Rita Eder acknowledged that certain styles, like surrealism, were deemed as more conducive for feminine expression (EDER, 1976: pp. 21-25). However, the existence of a movement based solely on supposedly feminine qualities was not received with enthusiasm. On the whole, most Mexican-based collaborators feared that adopting an essentialist strategy by making claims to difference would have a negative impact on recognition for women in the arts. They understood that most female artists, art critics and historians came from a privileged position and they acknowledged that this situation played a crucial role in smoothing the difficulties encountered within the dominant workings of the art system (STELLWEG, 1976; p. 2). Nonetheless, they did not recognize their own role in reproducing the patriarchal workings of the art world. In comparison to their US counterparts, Mexican-based artists and critics did not proposed an alternative corpus of theory and practice to the dominant cultural system or a critique of the role that art critics played in privileging certain artists over others. They also failed to address the ways images played a role in reproducing and producing normative gendered constructions and sexual difference.

Outside the established circles, a limited number of emergent young artists some of whom were also militants of the feminist movement began to describe themselves as 
feminist artists during the 1970s (MAYER, 2007: pp. 401-413; LARA, 2007: pp. 415-420). Mexican second wave feminisms were informed and in meaningful dialogue with international currents of feminisms - particularly, but not exclusively, with United States and Italian women's movements (LAU, 1987; LAMAS, 2001). Taking into account how the practices of Fernández, Jiménez and Mayer were enunciated from, and responded to, their local context, I posit their interventions as part of a transnational network of female artists that sought political change through artistic expression. Specifically, by exploring the relations and encounters between Mexican and US based feminists artists, I propose a less transited, but still politically charged, route from which to explore alternative cartographies of the histories of feminist art. This perspective places Mexico City as an important site of enunciation and articulation of interdisciplinary and transdisciplinary practices in light of recent historical revisions on feminist art (BUTLER \& MARK, 2007) and Mexican post-1968 visual culture (DEBROISE, 2006).

12 The emergence of a differentiated feminist art movement in Mexico and, more importantly, an awareness of how feminisms could collaborate in dismantling the structures of the art establishment have been slow in effect change. In comparison to other areas of the humanities that adopted feminist theory and gender studies as crucial frameworks of analysis from the early 1980s onwards (BARTRA, 1999), this was not always a widespread practice in the field of art history and art criticism despite some important exceptions that began recovering women's places in the histories of art at that time (TIBOL, 1977; CORTINA, 1985).According to Cordero and Sáenz, one of the reasons art critics and historians have been generally late in adopting feminist frameworks in Mexico rests with the traditional function that both art and art historiography played as symbolic supports for the hegemonic discursive practices of the groups in power (CORDERO \& SAENZ, 2007; p. 6). As in other societies, additional factors at play included the gendered divisions of labor that deemed the high arts as an exclusively masculine territory, while the lower arts or crafts were deemed feminine ones. In Mexico, this division became more paradigmatic as popular culture and the pre-Hispanic past became the foundation for the development of a highly masculine school of art, Mexican Muralism, that would not only play an important role in the creation of a national imaginary, but would dictate the parameters of art criticism and historiography for most part of the twentieth century.

During the 1970s, feminism in Mexico was (and sometimes still is) mostly understood as an imported imperialist dogma that prioritized issues of sexual liberation over more pressing class-based and social justice agendas (OLCOTT, 2010). According to artist and scholar Maris Bustamante (personal communication, August 6, 2010), many young female artists in the 1970s feared the consequences of being labeled as feminists in a male-oriented art world. They worried they would be accused of being self-indulgent rather than politically committed.

The situation has still not improved substantially not withstanding various efforts at analyzing works of art through a feminist and gender perspective (VELÁZQUEZ,1998; BARTRA, 2008; ZAMORA, 2007; BARBOSA, 2008; MILLAN,1999; PECH, 2009). Recent art historical revisions of post-1968 visual culture continue to disregard new wave feminist endeavors as interdisciplinary and transdisciplinary art practices in and of themselves.This is particularly alarming in the context of recent scholarly attention to the work of many art collectives active in 1970s Mexico that incorporated similar 
strategies to that of feminist collectives such as Los Grupos, albeit with a completely different understanding of politics (DEBROISE, 2006).

The movement of Los Grupos consisted of a diverse assemblage of artist collectives, which beginning in the early 1970 s and up to the mid-1980s, attempted to reconstruct the relationship between visual arts and politics by taking art to the streets and experimenting with non-traditional aesthetic languages (performances, installations, street happenings, graffiti, everyday objects, video, and super8 film) (VAZQUEZ MANTECÓN, 1994; CARRILLO GIL, 1985). These groups responded to the particular context of Mexico City where a vibrant and wide-ranging counter-culture movement had taken hold on the streets a decade earlier and struggled to regain terrain in the context of president Luis Echeverría's violent crack down of radical activity. Los Grupos was further inspired by transnational proposals for a new definition of politically committed art that emerged throughout the Latin American region in the aftermath of the Cuban Revolution (1958). Manifestos for new approaches to film and photography, for example, foregrounded these media as weapons that could transform the social and economic realities of the region. Such weapons, however, were often wielded in highly gendered ways in which the masculinity and heroism of revolutionary fighters was glorified whereas women were mostly represented as companions of revolutionary leaders, as sexualized ethnic beauties, or as victims of class and racial disparities.

What distinguished Los Grupos from earlier Mexican attempts to bring art to everyday life was their regional and international focus. They were no longer concerned with a national framework, or in making art to construct a national identity, as was the case for previous art movements.Los Grupos also sought, and claimed, independence from state cultural institutions while still working within the system. The politics that most, but not all, of the collectives that belonged to Los Grupos movement were mainly geared towards fighting for workers rights, denouncing the forces of imperialism that oppressed Latin American countries and supported military dictatorships in many of them, as well asexploring the ways urban modernization had altered the lives of Mexico City's residents. Although several self-declared feminist artists collaborated in some collectives of Los Grupos movement, the plight of woman's labor and living conditions, her depiction as a sexual object and her overall discrimination were seen as secondary problems (MAYER, 2009). This attitude, critics charged, represented the way the Left side of the political spectrum discriminated against women. Against this backdrop, feminist activists engaged in a wide range of collective activities that were deeply subversive.

17 A great number of feminist activists had backgrounds in the media and the arts. They had experience in journalism, broadcasting, film and theater. Many of the activists were also concerned with dismantling the ways in which the media objectified female bodies as part of their demands for the right to control their own bodies. For instance, Rosa Martha Fernández published several articles in which she exposed how print advertisements reproduced normative gender roles as biological rather than cultural constructs (FERNANDEZ, 1972).Throughout the seventies several feminist activist published independent magazines in which they wrote articles on women's art (FEMmagazine,1976), they directed films, took photos, broadcasted radio shows, and staged street performances and concerts. Nonetheless, visual artists, art historians, and musicians have only recently been included in histories of post-1968 feminism, alongside studies on feminist film and journalism (GUTIERREZ, 2002; GARCÍA, MILLAN 
\& PECK, 2007). What I propose here is to trace the collaborations between some of these variegated group of women as feminists' artistic expressions in and of themselves in the context of the re-emergence of transdisciplinary and interdisciplinary collective art practices in 1970s Mexico. In doing so I am contributing to ongoing conversations that acknowledge the practices of these women as feminist argumentations that worked to change dominant perceptions about the lack of existence of a feminist critique or a feminist movement. But rather than conceptualizing a feminist art movement in the singular or a product of a charismatic personality or a closed disciplinary field, I follow Cornelia Butler's proposal to think of feminism 'as a relatively open-ended system that has throughout its history of engagement with visual art, sustained and unprecedented degree of internal critique and contained widely divergent political ideologies and practices" (BUTLER \& MARK, 2007; p. 15).

\section{¿Cosas de Mujeres? Feminist collaborations in 1970s Mexico City}

18 In 1978, Mónica Mayer and Ana Victoria Jiménez found themselves collaborating with Colectivo Cine-Mujer (1975-1981), a group of women dedicated to the production of films about social issuesestablished by Rosa Martha Fernández and Beatriz Mira, then students of film at Centro Universitario de EstudiosCinematográficos (CUEC).Rosa Martha Fernández (personal communication, September 19, 2010) was already a university professor of psychology when she decided to study film after her experience with Cooperativa de Cine Marginal, an earlier film collective that produced super-8 films, which served as communication tools between different worker unions across Mexico. In Coperativa de Cine Marginal, Fernández worked as a camerawoman and was responsible for filming a nation-wide protest by the female textile workers union from Medalla de Oro who marched from the city of Monterrey to Mexico City to demand better wages and job security (2010).

19 Fernández had first become politically active after witnessing the 1968 movement in Paris as a psychology student. She was then introduced to feminists' activism while studying Television production in Japan in 1972 (2010).Upon her return to Mexico and before establishing Cine-Mujer in 1975 she published several articles exposing and analyzing the sexist mechanisms of the advertising industry in the country and participated in various small feminist conscious raising groups and became a militant of Mujeres en Acción Solidaria, (MAS, 1971) Fernández's experiences shaped the direction of Cine-Mujer from 1975 to 1980 towards a preoccupation with unveiling the social mechanisms that oppressed women within the broader context of class struggle. In the words of Fernández, the films of Cine-Mujer were tools for raising consciousness and were never intended for the film industry (2010). From 1975 to 1985, Colectivo Cine-Mujer produced more than six films on issues such as abortion, rape, domestic violence, prostitution and also documented gatherings of women's organizations. At the time, issues of sexuality including rape and abortion were still taboo topics for the majority of Mexicans.But Cine-Mujer films not only disrupted norms in terms of content, they also disrupted cinematic and generic conventions by which women had been previously represented in film and proposed alternative modes of production and distribution (MILLÁN, 1999; RASHKIN, 2001). Cine-Mujer developed a team of women who tackled all aspects of the film industry including production, content and 
distribution. It developed its own mechanisms of distribution in collaboration with Universidad Nacional Autónomade México (UNAM) and through the establishment of an independent distributor, ZAFRA (MILLÁN, 1999; p. 115). Their films were shown through alternative networks of distribution and non-commercial spaces including women's collectives around the country, university forums and informal gatherings. In spite of scathing critiques from the established film community, several of their films were nominated for prizes and recognized by the Mexican film industry (MILLAN, 1999: pp. 114-117).

Ana Victoria Jiménez (personal communication August 2, 2010; July 22, 2013) collaborated in two films produced by Colectivo Cine Mujer directed by Fernández: Cosas de Mujeres (1975-1978) dealing with abortion and Rompiendo el Silencio (1979), which took on the issue of rape. Jiménez provided Fernández with photos for both filmsandboth Jiménez and Mayer collaborated with research for Rompiendo el Silencio.Both are black and white films shot in $16 \mathrm{~mm}$ that mixed strategies and conventions of fictional and documentary films. They featured interviews, statistical data, still photography and a fictional narrative.

21 Screenings of Cosas de Mujeres were featured in campaigns to decriminalize abortion and they functioned as a didactic tool to promote discussions around these issues organized by Coalición de Mujeres, a broad coalition of several feminist collectives established in 1976. The film's title ironically refers to a phrase used to diminish the importance of an issue. Anything that was deemed to be a woman's issue was not relevant for public discussion nor pertinent to broader social, cultural and political fields. The film covers all the chief concerns that surrounded the issue of abortion at the time, including how abortion affected all social classes and the various responsibilities of health and governmental officials.

The film is held together by means of a central fictional narrative that tells the experience of Paz, a 19-year-old sociology student, played by Patricia Luke, in trying to obtain an abortion. We are shown how the student, having no one else to turn to, seeks help from a friend to find a doctor who will agree to perform an abortion. The story of the student is interrupted by the testimony of an older woman, from another social strata, who narrates her experience with abortion and sexual abuse. The film continues in a hospital, where we see numerous women on the verge of giving birth as well as being treated for the effects of induced abortions.Women's bodies are carried through hospital hallways, inspected with speculums or medicated as we listen to how doctors question them about the reasons of their condition. 
Figure 1. Fernández, Cosas de Mujeres, (still shot)

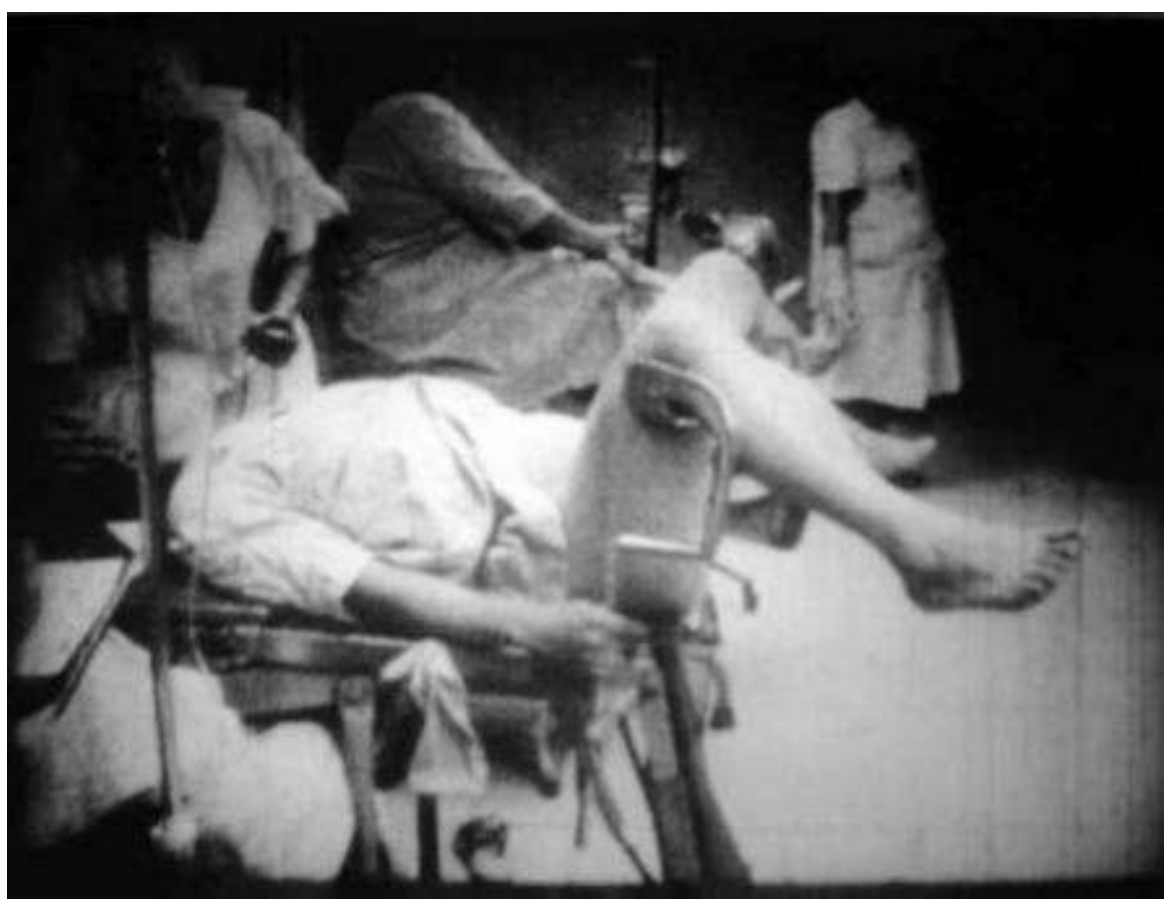

Courtesy of the artist

The images of female bodies being examined in the hospital fade and then come back into focus as the viewer is presented with statistics on abortion, newspaper clippings and interviews with several doctors. The film ends with a series of still images that show various groups of women in Italy, the US and Japan demonstrating in favor of the decriminalization of abortion. The last shot is a still image taken by Ana Victoria Jiménez. In this image we see Mexican feminists demonstrating outside the chamber of deputies in Mexico City in November 1977, as part of the campaigns to decriminalize abortion. 
Figure 2. Fernández, Cosas de Mujeres (still image)

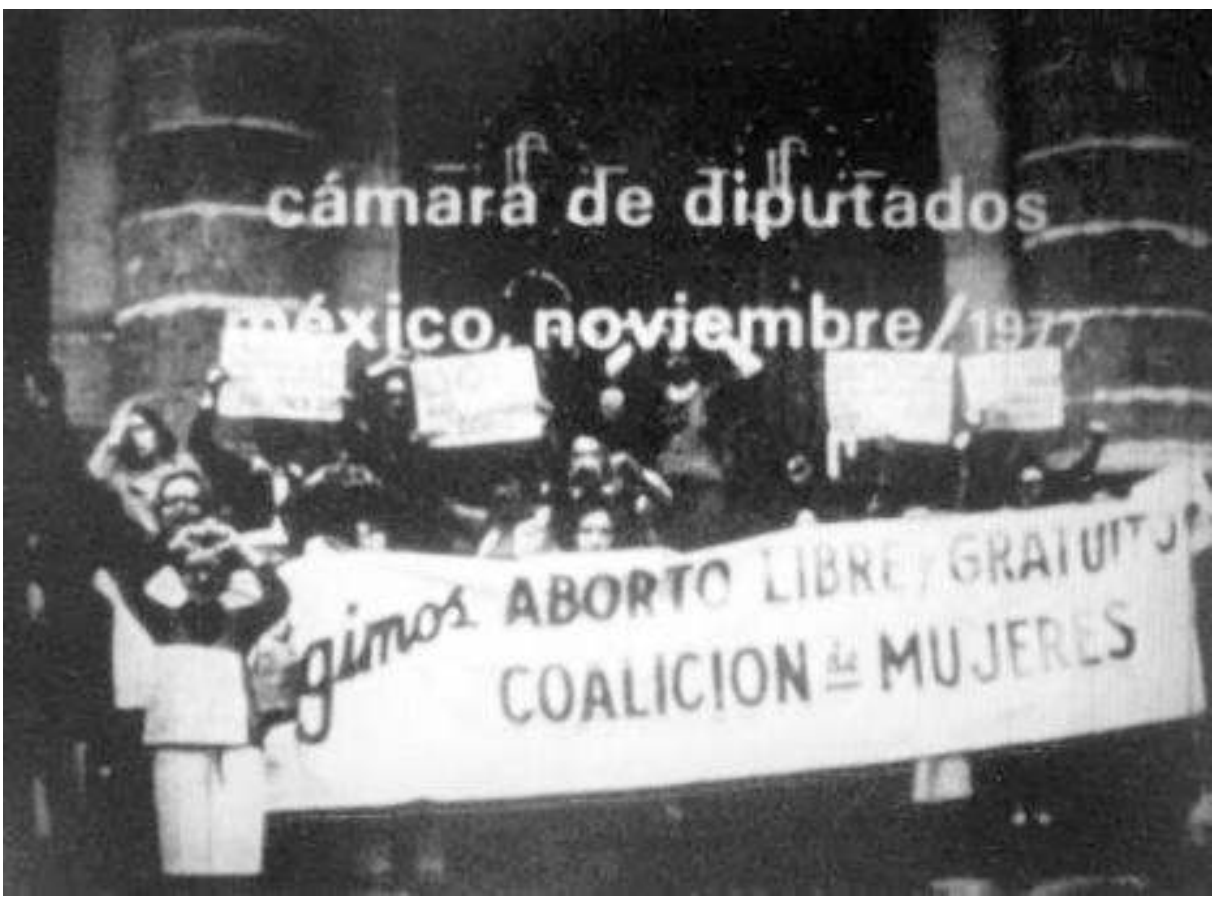

Courtesy of the artist

Fernández's incorporation of Jiménez's still image depicting feminist-led demonstrations contributes to the 'reality effect' of this film (BRUZZI, 2000). Jimenez's photographs contextualized the Mexican feminist movement in terms of a global fight for women's issues. Her images gave international relevance to the small group of Mexican women who demanded the right to control their own bodies. Jiménez's photographs also acquired political and historical weight through these films. As Andrea Noble argues:

... for demonstrations to achieve an impact beyond the localized public spaces in which they take place, they depend on the presence of photographers and film crews to create a widely disseminated spectacle of protest (...) their political agency is predicated in their ability to travel across media and space, thereby appealing to a broader national and international community of viewers (NOBLE, 2009: p.71).

Similarly, in Rompiendo el SilencioFernández also made use of Jiménez's photography to develop a reality effect. Throughout the film, interviews and statistical data on rape are woven together with three main testimonies - one by a rapist in jail, another by a young militant worker and a third by a married woman, the latter two having been raped. For this project, Fernández interviewed people on the streets of Mexico City, questioning them about their perceptions of rape. Some questions revolved around whether they thought that a woman who had been raped had lost her social standing and whether rape was perceived as a violent and forceful act or the result of female provocation. Some questions aimed at interrogating class-based perceptions of rape while others inquired about whether men raped women on the basis of an alleged biological necessity to satisfy sexual needs. Black and white images of the people interviewed are frozen in time as we listen to their responses in real time. Arguably, the stillness of the images makes the viewer more aware of the voices of those being 
interviewed. It further allows the viewer time to scrutinize the faces, to identify them, thus adding a dramatic tone to their responses.

Figure 3. Fernández, Rompiendo el Silencio (still image)

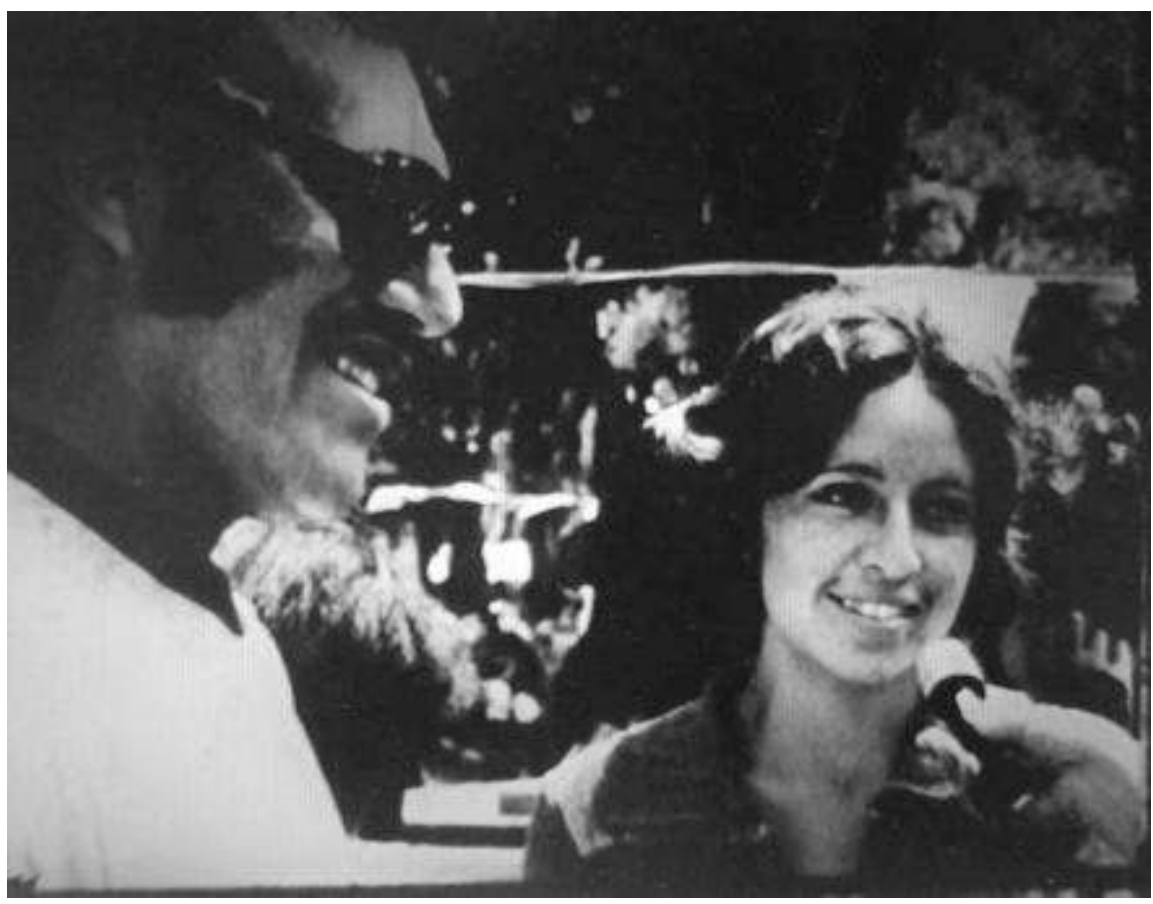

Courtesy of the artist

As we listen to the responses of all kinds of city dwellers, the still images unveil and posit the issue of rape as a public theme open to discussion (which as the title of the film indicates, it wasn't).As in the previous film, Jimenez's photographs were crucial to the development of a reality effect, giving the documentary a sense of relevance to the present but also endowing it with credibility as a source of knowledge.

7 In both films directed by Fernández, the female body is represented as both vulnerable and grotesque. We are shown graphic images of female bodies having clandestine or induced abortions in private clinics and public hospitals of Mexico City.We are also presented with vivid descriptions of how female bodies were raped and abandoned on the streets. In contrast, female bodies are also framed as politically active: demonstrating on the streets of Mexico, demanding sexual and reproductive rights and voicing their opinions through interviews.

These representations provide an alternative repertoire to common depictions of the female body (the prostitute, the sexual symbol, the matriarch, the victim, the small girl or the sacrificed mother) that circulated in films at the time (BERG, 1992) Fernández's films break with representations of the female body as something virginal and taboo, whose interiors are relegated to the private sphere.In bothfilms the female body is opened up for public scrutiny. Both films expose and locate the female body as central in the articulation of cultural and political violence as experienced in the streets of Mexico City and show a how a variety of discursive practices are involved in producing such articulations. Moreover, they invited, and continue to invite, viewers to interrogate their own lives. 
When Ana Victoria Jiménez (JIMÉNEZ, 2010) began to collaborate with Cine-Mujer she worked in the graphic arts industry and was already a seasoned political militant. Previously, she had acted as the representative of Union Nacional de Mujeres Mexicanas (UNMM), a group of women mostly affiliated with the Mexican Communist Party, at the International Democratic Federation of Women (FDIM) in Berlin.Earlier she had been a militant of the Communist Youth Leagues (IBID, 2010).She studied graphic arts at $E l$ Sindicato de los ArtistasGráficos in the early 1960s, after which she combined her practice as a photographer with her career as independent editor and publisher.Jiménez interest in photography originated around 1971 as she began to participate in several second wave feminist demonstrations and started to develop an interest in documenting these gatherings. It was also at this time when she began to collect graphic ephemera that, along with her photographs and documentation of her artwork, now constitute a valuable, but only recently recognized visual archive of the histories of feminisms and post-1968 Mexico. (MUJERES ¿Y QUE MAS ?, 2011: MAYER, 2009).In 2011, her archive was donated to the library of Universidad Iberoamericana in Mexico City, a private academic institution, as part of an initiative by a group of scholars and artists, including Mayer, who workedonactivating Jiménez's collections(MAYER, 2009).

Throughout the 1970s, Jiménez participated in more than a dozen feminist demonstrations and belonged to various feminist collectives. These demonstrations brought not only a new set of issues, including abortion, sexual rights, concerns for the ways women were represented in the media, but also a different way of performing and advocating for those issues in public. Through her participation in feminist collectives her political ideology began to change as the demands of this new generation of women veered away from the class-based focus of earlier women's movements in which she had been involved. Jiménez became acquainted with a variegated group of women who were concerned with issues of gender equality and sexual rights. These demonstrations focused on a new set of issues and they also brought different ways of performing and demanding them in public. Unlike union or political party demonstrations, feminist demonstrations were "más alegres, con más idea de lo visual, con una forma particular de expresarse en sus pancartas." (JIMÉNEZ, 2010). This difference, she tells me, inspired her to take photos and collect ephemera more rigorously. For Jiménez, these political gatherings were much more visually interesting than any other street protest in which she had participated. 
Figure 4. Jiménez, Coalición de Mujeres Feministas, 1976-1979

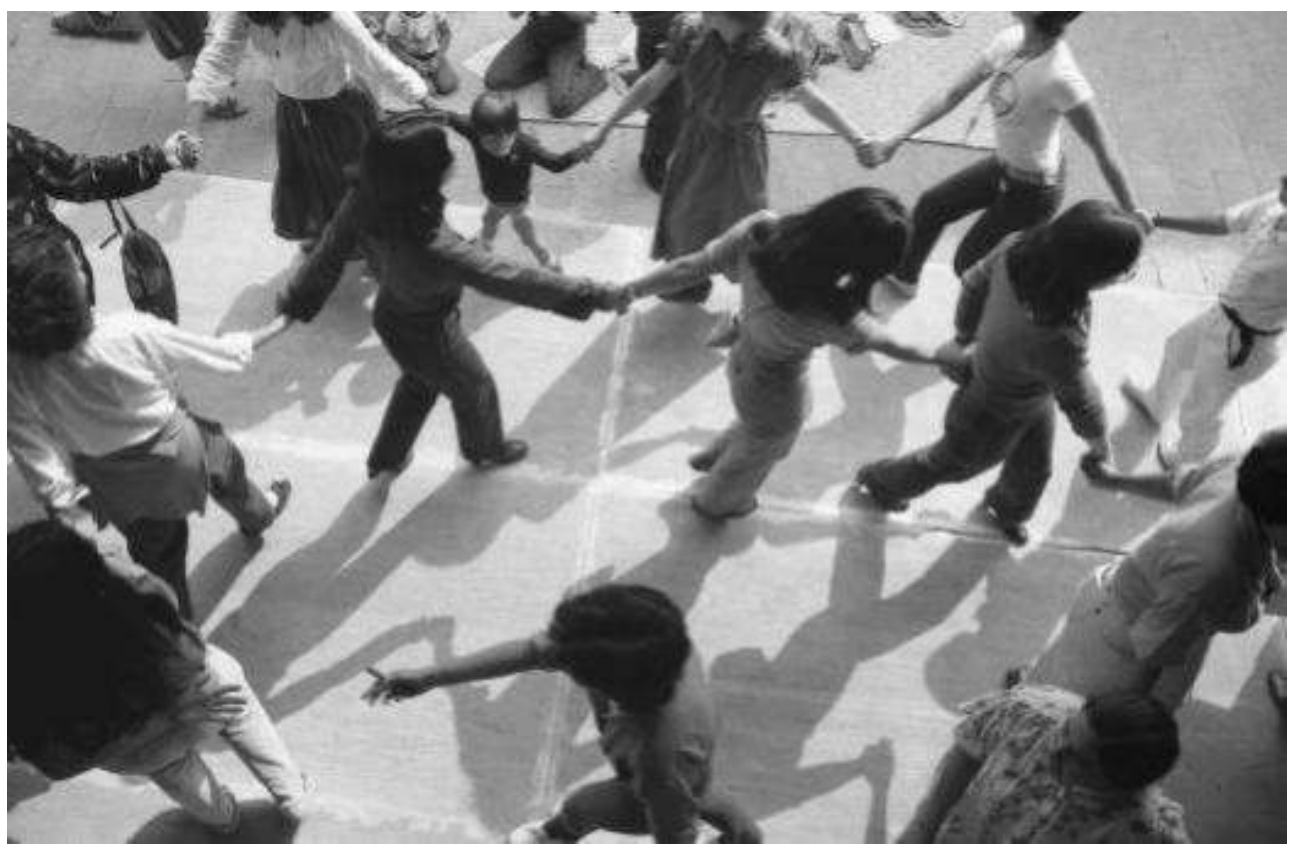

Courtesy of the artist

31 At a time when photography was being valued for its documentary potential in Mexico, as elsewhere, and many women photographers began to gain recognition for their images depicting representations of Mexican femininity as the exotic indigenous Other or symbols of mythical matriarchal organizations (such as the work of Graciela Iturbide in Juchitán), Jiménez chose to point her viewfinder towards women who, like her, demanded their rights to self-representation on the streets of Mexico City. While Jiménez's photos do not figure in the archives of any specific genre of Mexican photography, her images do provide an alternative visual narrative about Mexican femininity, its politics and its desires. It is was a narrative that represented issues that were not important for the kind of documentary photography Latin American photographers were becoming well known for at the time (CONSEJO MEXICANO DE FOTOGRAFÍA, 1978)

32 As Jiménez took photographs and collaborated along with Mayer in Fernández's movies, Mayer began to identify herself as a feminist artist and exhibit her works in several art venues in Mexico City (MAYER, 2007). Most famously she presented an installation entitled El Tendedero in the 1977-1978 New Trends Biennial at the Museum of Modern Art (MAM) in Mexico City (MAYER, 2009).El Tendedero consisted of a series of small pink papers attached by clothes pins to strands of yarn. The resulting space resembled the place where women in Mexico City conventionally went to hang laundry to dry. On each piece of paper, Mayer wrote the question "as a woman what do I hate most of the city?" and distributed the small pink papers to various women from different backgrounds and ages in diverse parts of the city. At MAM, many other women wrote responses on the pink pieces of paper and were added to the exhibit. The answers ranged from feeling threatened to being called names such as mama cita or getting a nalgada. 
Figure 5. Mayer, El Tendedero, 1978

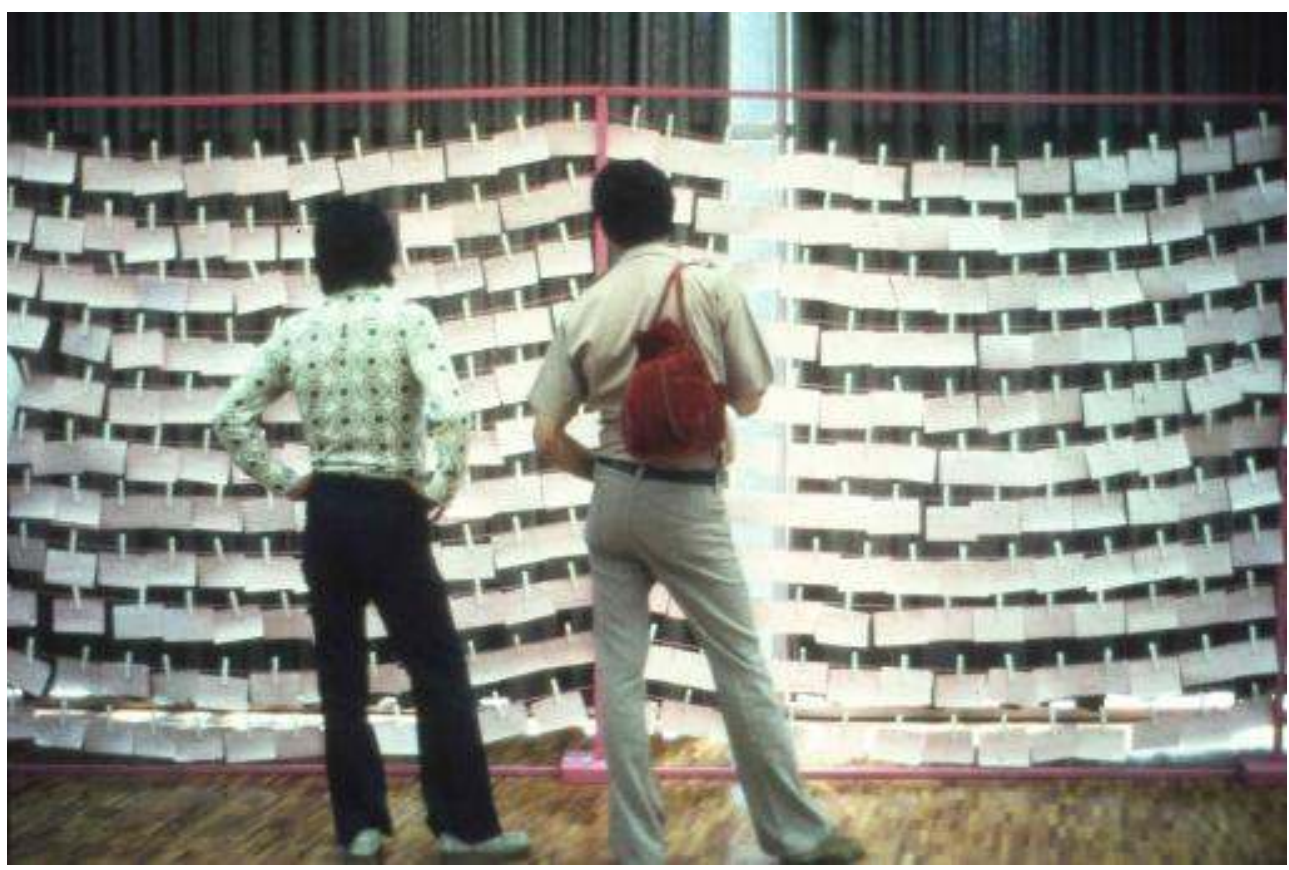

Courtesy of the artist

33 By placing a clothesline in an art gallery and exhibiting the ways in which women's experiences of urban space were mediated through their bodies in highly gendered and sexualized terms, El Tendedero transgressed the divide between the public and the private. Mayer's installation transformed a female domestic space into a public space. In doing so, it mapped out encounters, conceptions and desires between bodies and the ways in which these played a role in the production of urban space. El Tendedero placed the female body as a site of mediation where cultural, political and sexual violence were both produced and experienced in relation to the city. In this map, the female body emerged as one that was readily threatened and only ascribed value in sexual terms. El Tendedero, then, is a statement about how the politics of gender and sexuality are present in every day life situations, dissolving the boundaries between the private and the public as well as the personal and the political.

At the time this piece was exhibited in Mexico, Mayer was about to begin her studies at the Feminist Studio Workshop of the Women's Building in Los Angeles, California (WAB).Mayer had learned about WAB through the 1976 edition of ArtesVisuales. Before leaving for LA, Mayer had begun to participate in the feminist collective Movimiento Feminista Mexicano, (MFM, 1976) and had already attempted to establish a feminist group show of militant art that resulted in an art exhibition at La Galería Contraste (MAYER, 2007). Mayer's experience in LA introduced her to a group of feminist's artists and activists interested in effecting change through interdisciplinary and collaborative art practices.

35 Fernández movies and Mayer's installation shared an interest in transforming spaces and concerns deemed as exclusively feminine into a politically relevant and public concern that involved all kinds of social, political and cultural fields and practices. Reading El Tendedero and Fernández's movies together shows how they were both invested in a feminist practice that unveiled how normative gender roles and sexual 
difference were constructed through everyday discursive practices and silenced cultures of violence.

Fernández movies and Mayer's installation also share an interest in incorporating sociological strategies such as interviews in their art practices. These experiences would shape Mayer's work into a practice that mixed aspects of sociologically motivated art that employed interdisciplinary strategies and performative modalities. This kind of sociological approach to art was in close dialogue with projects and practices of other feminist artists and activists, as well as with emergent strategies of conceptual art worldwide.

El Tendedero also works as a kind of archive. Reading it alongside the archival practices of Jiménez, puts current academic interests in the archive and specifically artists' archives, into perspective (ARCHIVOS DEL ARTE ACCION EN MEXICO, 2009). Formally, El Tendedero resembles one of the most ancient practices of filing important things. As Sven Spieker recalls "hanging or stringing up objects to a rope was one of the first forms of filing" (SPIEKER, 2008; p. 1). Even nowadays, many agree that archives come into being 'when several documents that share a common subject are combined by either physically tying them together in a binder of some sort or grouping them as a loose collection (IBID: p. 24)." Most interesting and in light of recent scholarship on the nature of archive, El Tendedero interrogates and furthers the notion of an archive through the kind of information it seeks to record and how it does so (TAYLOR, 2003; MUÑOZ, 1996; CVETKOVITCH, 2003; DANBOLT, 2009). By explicitly proposing to gather information about the ways in which sexual difference was constructed and experienced through the streets of Mexico City, Mayer's archive records and represents embodied emotions and encounters as they take place in, and are mediated through, an urban space. The body is thus unveiled as a crucial component in the production of urban space and how in turn the city produces sexed and gendered corporealities (GROSZ, 1995).

Mayer and Jiménez would collaborate on various projects after their initial efforts. Several aimed to build links with US-based feminist artists and establish Mexico City as a stage in the transnational feminist art movement. On February 14, 1979, US based feminist artists Suzanne Lacy, began a global project entitled "International Dinner Party" to honor her mentor, Judy Chicago, in the context of the first exhibition of Chicago's Dinner Party at the San Francisco Museum of Modern (SF MOMA). Lacy's international version of the Dinner Party consisted of hosting dinners, all on the same evening of Chicago's opening, to honor women in their local and regional contexts. At each dinner, women collectively wrote a statement that was sent back to Lacy via telegram. At SF MOMA, Lacy marked each dinner with a red inverted triangle on a twenty-foot black and white map of the world. In Mexico City, a dinner was hosted at the house of Lilia Lucido de Mayer (Mónica Mayer's mother and militant of various feminist collectives) to honor Adelina Zendejas, Amalia Castillo Ledón, Elvira Trueba and Concha Michel, important women in the post 1920 period who fought for social causes (JIMÉNEZ, 2010). 
Figure 6. Dinner party at Lilia Lucido de Mayer's housewith

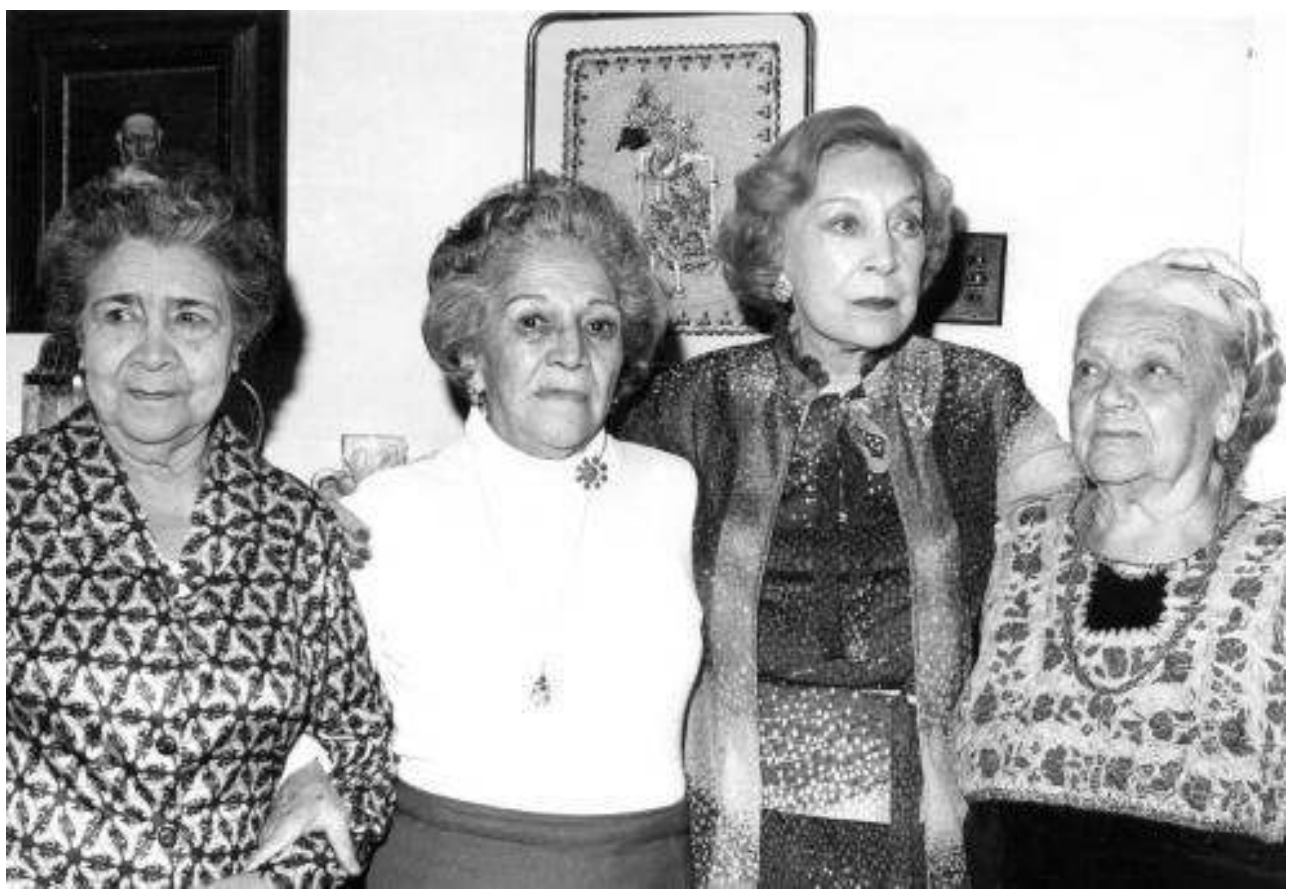

Elvira Trueba, Adelina Zendejas, Amalia Castillo Ledónand, Concha Michel

Courtesy of the artist

This event went unnoticed in Mexico City's art circles, but began to draw connecting lines between different women and conceptions of art and feminism and possibly furthered the use of more visually compelling material at feminist demonstrations. Early on, feminist demonstrations had incorporated songs and street plays, but after the dinner party, on March 10, 1979, Jiménez and Lila Lucido de Mayer, along a group of feminist activist affiliated to Movimiento Nacional de Mujeres (MNM, 1972) dressed in black and marched towards the Mother's Monument. This time, their march was a protest against the rising number of abortion-related deaths as well as the exploitation of Mother's Day by mass media and governmental organizations. They carried a huge funeral wreath, which instead of being made of flowers, was made of objects utilized to induce abortions: knitting needles, cloth hangers, turkey feathers and natural herbs. 


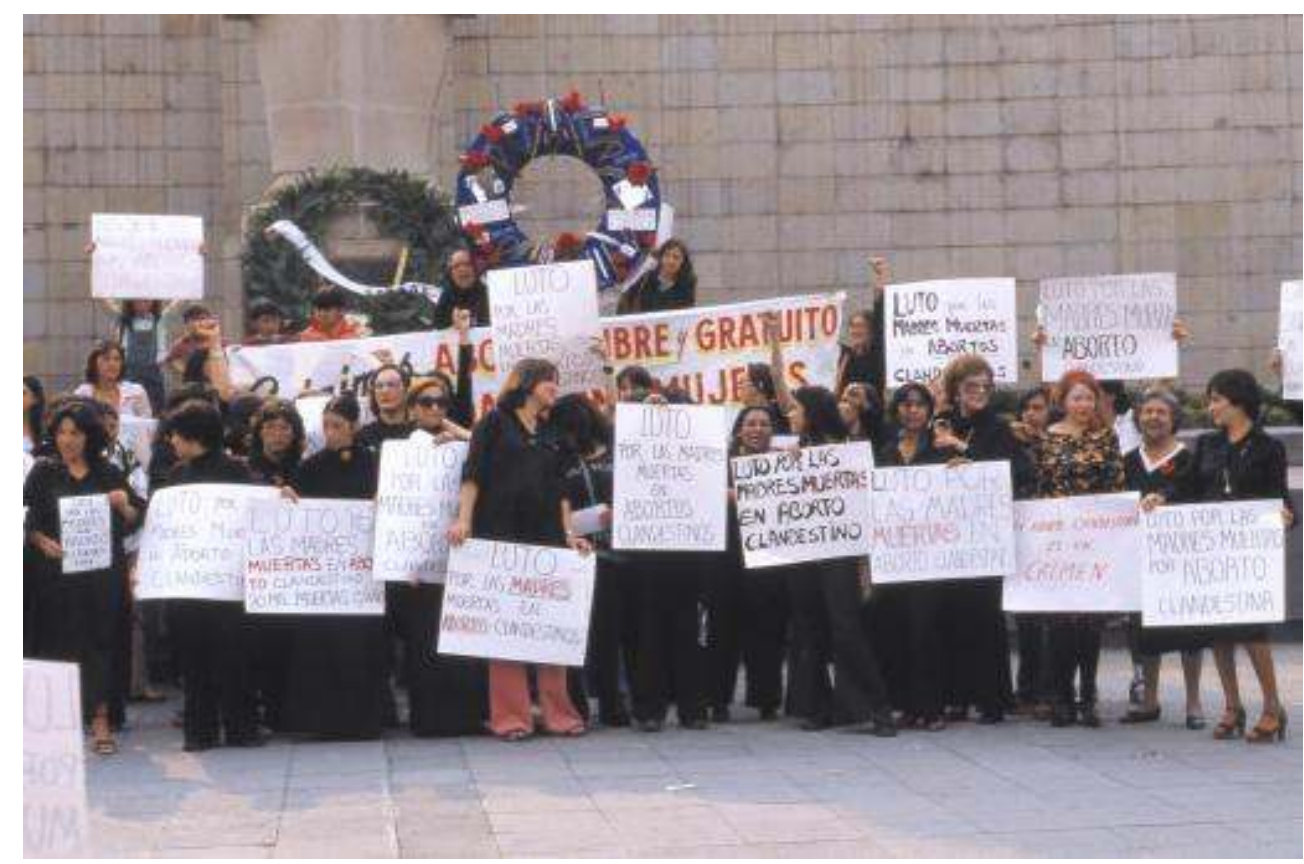

Courtesy of the artist

The performative practices used in this demonstration linked diverse groups of women who resorted to the cultural archetypes of motherhood and mourning to voice competing demands of social justice throughout the Americas, from the Argentinian Mothers of Plaza de Mayo who demanded justice for their disappeared sons and daughters (1976), to US-based Labowitz and Lacy's demonstrations against violence against women (1977). These performative practices were both transnationally and locally informed. In addition to the collaborative network of Fernandez, Mayer and Jiménez discussed previously, a later encounter organized by Mayer and three US based artists, Jo Goodwin, Denise Yarfitz and Florence Rosen, on December of 1979 reveals the simultaneously transnational and localized conception of visual art and politics that operated in Mexico in the 1970s. The project entitled Traducciones: Un Diálogo Internacional de Mujeres Artistas consisted of generating dialogues and encounters between Mexican and US-based feminists (MAYER, 2009). The meeting with more than sixty women from all over the country in attendance, including some who had never been involved with feminism, was not a very successful experience according to Mayer (IBID, 2009). The Mexican attendees were generally disappointed by the discussions, which centered on the relation between art and politics rather than on women's oppression (MAYER, 1979).In spite of this set back Mayer would continue to promote feminist art in Mexico in the decades to follow.

41 Out of the three women discussed in this article, Mónica Mayer was the only one trained as a visual artist and the only who had an interest in building a career as a feminist artist While Jiménez and Fernández were not so invested in becoming artists or creating a feminist art movement per se, the aesthetic collaborations of these three women created ripples through various fields. And in doing so they collaborated in the creation of a movement, one that was not solely concerned with one disciplinary field or an individual. 

promote the establishment of various feminist art collectives, among them Tlacuilas and Retrateras (1984) in which Jiménez participated. Along with fellow artist Maris Bustamante, Mayer also established the feminist collective Polvo de GallinaNegrastaging performances that questioned traditional women's roles. Currently, she continues to promote and write on feminist art practices. Along with her partner Victor Lerma, Mayer established Pinto Mi Raya, a virtual space conceived as an archive of sorts for the dissemination and preservation of art criticism.

After Tlacuilas y Retrateras broke apart in 1984 Jiménez took a prolific role in the publication of memoirs of various activists and in writing the history of the UNMM, using her personal archive as a major source. At present, she continues her activism through a project dedicated to helping elderly women achieve a dignified quality of life. In the early 1980s, Fernández left Cine-Mujer and volunteered with the Sandinistas in Nicaragua where she produced television programs for women and children and directed movies until her return to México in 1984 (FERNANDEZ, 2010). Currently, she continues to produce films and documentaries that deal with social causes, particularly those that affect women.

\section{Conclusion}

The 1970s was tumultuous decade in Latin America in which many groups sought to rekindle the relationship between art and politics. 1970s feminism, in Mexico, and elsewhere actively took part in this process by arguing that the personal was also political. Following this dictum, the collaborations of Rosa Martha Fernández, Mónica Mayer and Ana Victoria Jiménez attest to the existence of a more fluid and wider, however, no less contested, definition and practice of politics. Theirs was an alternative conception to those of the ideological Left, the parameters of Latin American artistic solidarity and dogmatic definitions of feminism. Their practices were in and of themselves feminist argumentations that destabilized the patriarchal structures that ruled art institutions and defined parameters of art making. The works and collaborations of these three artists propose and demonstrate how feminism can be understood as critical form of inquiry, engaged in unveiling how diverse structures of power and categories of difference are at work in visual representations. Byrecording information on feminist activism and feminist artists, Jiménez's archive and archival practice challenges what was deemed valuable as a historical source and how the histories of feminism have been written. Her archive not only documents the history of the feminist movement, but also the emergent and marginal histories of feminist interventions in the arts. Moreover, her photos add an alternative to traditional representations of Mexican femininity politics and desires. Similarly, the films in which Fernández, Mayer and Jiménez collaborated broke with established cinematic visual representations of the female body. Moreover, Colectivo Cine Mujer proposed an alternative to methods of distribution, production and circulation of films. For her part, Mayer's earlier work mapped out embodied encounters and recorded information about sexual desires and fantasies, as they were experienced on the streets of Mexico City. In doing so she made explicit how urban embodied encounters shaped sexual difference and normative gendered behaviors. Their activities as photographers, archivists, filmmakers and visual artists played a role in discrediting the disciplinary 
and hierarchical boundaries of art history discourses that were traditionally privileged in the study of how images produced meanings. They proposed different ways of producing and recording knowledge thus questioning what counted, and continues to count, as valid sources for historical narratives.

While Mayer figures prominently in the network I traced in this paper (indeed, she has been a leading figure in promoting a feminist art practice in Mexico), a number of other networks of collaboration emerged from the 1970s feminist collectives. All these women came from distinct disciplinary backgrounds and slightly divergent political ideologies. Many of these collaborations also led to important experiments with visual and performative languages such as the street plays and performances staged by members of Movimiento de Liberación de la Mujer (1975),La Revuelta(1976)and Las Leonas (1979).Most members and militants of feminist collectives active during the 1970s went on to built careers as academics, film and theater directors and establish gender and women studies programs. It is perhaps at this time, with some historical distance, that the wide-ranging cultural legacies of the transdisciplinary and interdisciplinary practices of all these women can be integrated more fully in narratives of feminisms, art history and social movements without dismissing them as cosas de Mujeres.

\section{BIBLIOGRAPHY}

ACEVEDO, M. (1970). 'Nuestro Sueño está en Escarpado Lugar. Crónica de un Miércoles Santo entre las Mujeres (Women's Liberation - San Francisco)'.In La Cultura en México, Siempre!.

September 30.

BARBOSA, S. A. (2008). Arte feminista en los ochenta en México: Una perspectiva de género. México: Casa Juan Pablos.

BARTRA, E. (1999). 'El movimiento feminista en México y su vinculo con la academia'. In La Ventana, 10, 214-232.

BARTRA, E. (Ed.) (2008). Museo vivo: La creatividad femenina. México: Casa Abierta al Tiempo.

BERG, C. R. (1992). Cinema of solitude: A critical study of Mexican film, 1967-1983. Austin: University of Texas Press.

BRUZZI, S. (2000).New Documentary: A Critical Introduction. London: Routledge.

BUTLER, J. (1993). Bodies that matter: On the discursive limits of 'sex'. New York: Routledge.

BUTLER, C. H. and MARK, G.L (Eds.) (2007). WACK! : Art and the Feminist Revolution. Los Angeles: Museum of Contemporary Art.

BURTON, A. (2003). Dwelling in the Archive: Women Writing House, Home, and History in Late Colonial India. New York: Oxford UP.

CORTINA, L. (1985). Pintoras mexicanas del siglo XIX [catalogue] México: Museo de San Carlos INBA, 1985. 
CORDERO, R. K., \& SÁENZ, I. (2007). Crítica feminista en la teoría e historia del arte. México: Universidad Iberoamericana y UNAM-PUEG.

Consejo Mexicano de Fotografía (1978). 'Fondo CMF'. In Fondos Especiales, Biblioteca Nacional de las Artes, México.

CULLEN, D., \& Bustamante, M. (2008). Arte [no es] vida: Actions by artists of the Americas 1960-2000. New York: El Museo Del Barrio.

CVETKOVICH, A. (2003). An archive of feelings: Trauma, sexuality, and lesbian public cultures. Durham, NC: Duke University Press.

DANBOLT, M., Rowley, J. and WOLTHERS, L. (Eds.) (2009). Lost and Found: Queerying the Archive. Copenhagen Contemporary Art Center Bildmuseet University.

DEBROISE, O. (2006). La era de la discrepancia: Arte y cultura visual en México, 1968-1997.México: Universidad Nacional Autónoma de México.

FERNÁNDEZ, R.M. (1972) “La Mujer Mexicana y la Conciencia de la Opresión.” In La Cultura en México, Siempre!, Jul-Sept, $\mathrm{x}$-xi.

FERNÁNDEZ, R.M. (Director, Producer) (1975-1978). Cosas de Mujeres (motion picture). Mexico.

FERNÁNDEZ, R.M. (Director, Producer) (1979). Rompiendo el Silencio (motion picture).Mexico.

GARCÍA, N. N., MILLÁN, M., \& PECH, C. (2007). Cartografías del feminismo mexicano, 1970-2000. México: Universidad Autónoma de la Ciudad de México.

GUTIÉRREZ, C. G. (2002). Feminismo en México: Revisión histórico-crítica del siglo que termina. México: Universidad Nacional Autónoma de México.

GROSZ, E. (1995). Space, Time and Perversion. Routledge: New York and London.

JONES, A. (2010). The feminism and visual culture reader. London: Routledge

LAMAS, M. (2001). Política y reproducción: Aborto: la frontera del derecho a decidir. México: Plaza y Janés.

LARA, M. (2007). 'La memoria es como una piedra púlida.' In Crítica feminista en la teoría e historia del arte, 415-420.

LAU, J. A. (1987). La nueva ola del feminismo en México: Conciencia y acción de lucha de las mujeres. México: Planeta

LIPPARD, L. (1976) “ ¿Porque separar el arte femenino?’ In Artes Visuales, 31-36.

MAYER, M. (1979). Traducciones; Un Dialogo Internacional de Mujeres Artistas. Mexico.

Mayer, M. (2007). 'De la Vida y el Arte como Feminista.' In Crítica feminista en la teoría e historia del arte, 401-413.

MAYER, M. (2004) Rosa Chillante. Mujeres y Perfomance en México. Pinto Mi Raya, CONACULTA: México.

MENDEZ, J.C. (1977). 'Hacia un cine politico: La Cooperativa de Cine Marginal'. In La Cultura en México, Siempre!, July 19, ix-xiii.

MONSIVÁIS, C. (2006) “When Gender Can't Be Seen amidst the Symbols: Women and the Mexican Revolution." In Olcott, Vaughan and Cano (Eds) Sex in Revolution. Gender, Politics and Power in Modern Mexico.Duke University, 1-20.

MILLÁN, M. (1999). Derivas de un cine en femenino. México: M.A. Porrúa. 
MOSSER, C. (1976) “El Mundo Interior y Exterior del Movimiento Artistico Femenino" In Artes Visuales, 37-42.

Mujeres ¿y qué más? Reactivando el archivo de Ana Victoria Jiménez (2011). Retrieved from http:// archivoavj.com/

MUÑOZ, J.E. "Ephemera as evidence: Introductory notes to Queer acts" in Women and Perfomance, 8(2) 1996, 5-16.

Museo de Arte Carrillo Gil (1985).De Los Grupos a Los Individuos [catalogue]: México: MACG. NOBLE, A. (2009). "Family photography and the global drama of human rights." In Long, J. Noble, A. and Welch, E. Photography: Theoretical Snapshots. London: Routledge, 62-71.

OLCOTT, J. (2012) "Cold War Conflicts and Cheap Cabaret: Sexual Politics at the 1975 United Nations International Women's Year Conference.” In Gender \& History, 22 (3), 733-754.

PECH,C. (2009). Fantasmas en tránsito: Prácticas dicursivas de videastas mexicanas. México: UACM. POLLOCK, G. (2012). 'Unexpected Turns: The Aesthetic, the Pathetic and the Adversarial in the Long Durée of Art's Histories'. In Journal of Art Historiography, 7, 2-32. Retrieved from http:// arthist.net/archive/4358

RASHKIN, E. (2001). Women filmmakers in Mexico: The country of which we dream. Austin: University of Texas Press.

SCHNEIDER, R. (2002) “Archive Performance Remains.” In Performance Research, 6 (2), 100-108.

SCOTT, J. (1986). 'Gender as a Useful Category of Historical Analysis.' In American Historical Review, 91(5), 1053-1075.

STELLWEG C. (ed.) (1976). Mujeres /Arte/ Femineidad. In Artes Visuales, 9. México: Museo de Arte Moderno.

STOLER, A. L. (2002). "Colonial Archives and the Art of Governance: On the Content in the Form." In Carolyn Hamilton, Refiguring the Archive. Cape Town, South Africa: David Philip, 83-100.

STOLER, A. L. (2009) Along the Archival Grain: Epistemic Anxieteis and Colonial Common Sense. Princeton University Press.

SPIEKER, S. (2008).The big archive: Art from bureaucracy. Cambridge, Mass: MIT Press.

TAYLOR, D. (2003). The archive and the repertoire: Performing cultural memory in the Americas. Durham: Duke University Press.

TIBOL, R. (1977). Frida Kahlo: Crónica, testimonios y aproximaciones. México: Ediciones de Cultura Popular

VELÁZQUEZ GUADARRAMA, A. (1998) 'El Amor del Colibrí de Manuel Ocaraza' and 'Escena Familiar.' In Memoria, 7, México: MUNAL, 134-136; 103-107.

VELÁZQUEZ GUADARRAMA, A. (1998) 'Castas o marchitas. 'El amor del colibrí' y 'La flormuerta' de Manuel Ocaranza' in Anales del Instituto de Investigaciones Estéticas, 73, México: UNAM, 125-160.

VAZQUEZ MANTECÓN A. (Producer) (1994). Los Grupos[videorecordings]. México: Museo de Arte Carillo Gil.

ZAPATA, G. M. (2007) 'Feminist Movements in Mexico from Consciousness-Raising Groups to Transnational Networks.' In Femenías, M. L., \& Oliver, A. Feminist philosophy in Latin America and Spain. Amsterdam: Rodopi

ZORA, (1976) 'Zora entrevista a Judy Chicago y Arlene Raven." In Artes Visuales, 25-29. 
ZAMORA, B. L. (2007). El imaginario femenino en el arte: Mónica Mayer, Rowena Morales y Carla Rippey.

México: CENIDIAP.

\section{ABSTRACTS}

As second wave feminisms emerged throughout the world, diverse collectives and consciousnessraising groups were established in Mexico City as early as 1971. These activities gave rise to various networks of female artists who explored and politicized conceptions of the female body, making inroads in photography, performance, film and conceptual art. In this paper, I discuss the network established by Ana Victoria Jiménez, Rosa Martha Fernández and Mónica Mayer, who produced collaborative films and performances. Using gender as category of analysis, I discuss how their practices destabilized the patriarchal structures that governed art institutions in the city and defined parameters of art- making while simultaneously disrupting hegemonic visual conventions.

A partir de 1971 y dentro del contexto de la emergencia del feminismo de la segunda ola a nivel internacional un grupo de mujeres establecieron más de una docena de colectivos feministas en la ciudad de México. Entre muchas otras cosas, estos colectivos fueron puntos de encuentro para la creación de redes de colaboración entre artistas quienes exploraron el cuerpo femenino como un medio político. En este ensayo discuto la red establecida por Ana Victoria Jiménez, Rosa Martha Fernández y Mónica Mayer. Utilizo el género como una categoría de análisis para investigar la forma en que sus trabajos desestabilizan las estructuras patriarcales de las instituciones del arte y la producción artística así como transgreden convenciones hegemónicas de representación visual.

\section{INDEX}

Palabras claves: arte feminista, Ciudad de Mexico, performance, film, fotografia, archivos Keywords: feminist Art, Mexico City, performance, film, photography, gender, archives

\section{AUTHOR}

\section{GABRIELA ACEVES}

Gabriela Aceves Sepúlveda Candidata a Doctor en el programa de Historia en La Universidad de La Columbia Británica en Vancouver.

gaceve[at]alumni.ubc.ca 